\title{
Protective effect of aqueous extract of Alhagi maurorum in spermatogenesis and antioxidant status of adult rats exposed to carbon tetrachloride
}

\author{
M.A. Ahmed \\ Biology Department, College of education for Pure Science, Tikrit University, Tikrit, Iraq, e-mail: measer80@gmail.com
}

(Received March 29, 2018; Accepted April 19, 2018)

\begin{abstract}
This study aimed to investigate the efficiency of aqueous extraction of Alhagi maurorum leaves against oxidative stress induced by carbon tetrachloride $\left(\mathrm{CCl}_{4}\right)$ on spermatogenesis and the level of glutathione, superoxide dismutase, malondialdehyde in adult rats. Plant Leaf's dried and then extracted. Experiment included 24 male rats divided into 4 groups 6 subjects in each group. Groups treated orally for 30 days as following: first was control group which administered with $1 \mathrm{ml}$ of physiological saline $0.9 \%$, second group administered once with $\mathrm{CCl}_{4} 3 \mathrm{ml} / \mathrm{Kg}$, third and fourth groups administered with aqueous extract $300 \mathrm{mg} / \mathrm{kg}$ and aqueous extract together with $\mathrm{CCl}_{4}$ respectively. The results showed that $\mathrm{CCl}_{4}$ caused a significant decrease in sperm count, sperm vitality, normality, glutathione (GSH) and superoxide dismutase (SOD), significant increase in sperm mortality, abnormality and malondialdehyde (MDA) compared with control group. While aqueous extract treatment caused no significant difference in compare to control group. Groups treated with aqueous extract together with $\mathrm{CCl}_{4}$ showed a significant increase in sperm count, vitality, normality and GSH and decreasing in mortality, abnormality and MDA in compare to $\mathrm{CCl}_{4}$ group. It could be concluded that the aqueous extract of Alhagi maurorum have a positive effect on male reproduction and antioxidants in rats exposed to oxidative stress.
\end{abstract}

Keywords: Alhagi maurorum, $\mathrm{CCl}_{4}$, spermatogenesis, GSH, SOD, MDA

Available online at http://www.vetmedmosul.com

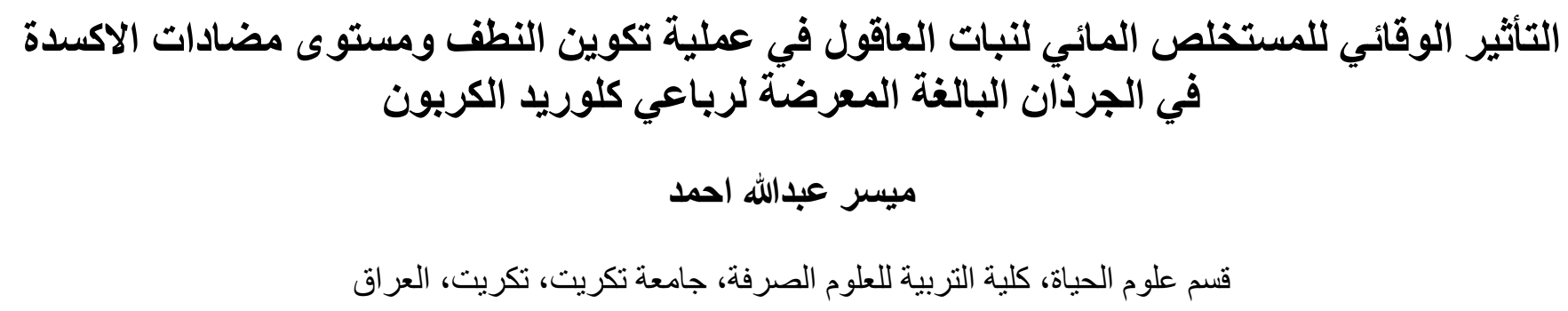

الخلاصة

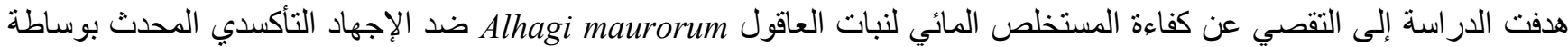
رباعي كلوريد الكربون (CC14) في عملية تكوين النطف وحالة مضادات الأكسدة في ذكور الجرذان البالغة. جفقت اوراق الإنة النبات ومن ثم

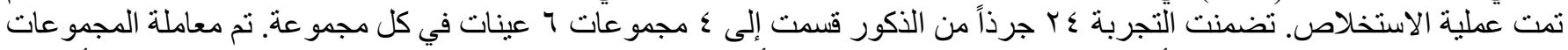

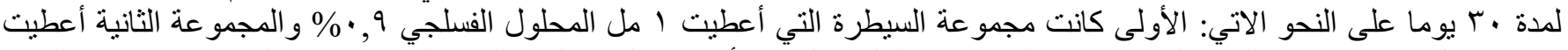

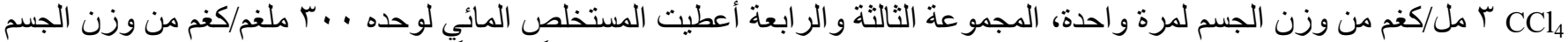

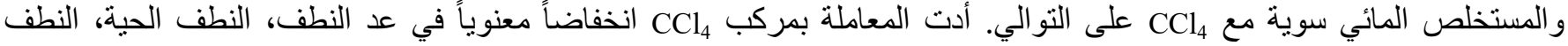

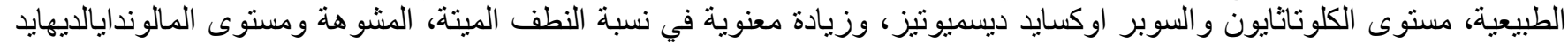

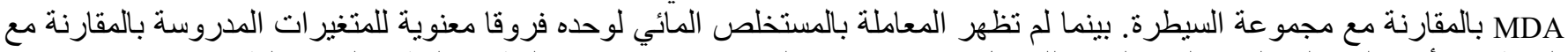

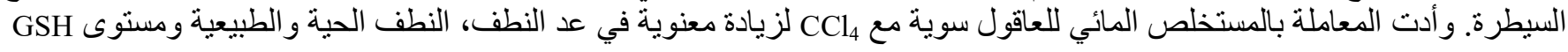




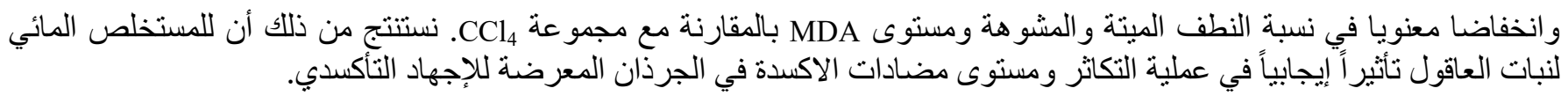

\section{Introduction}

Male fertility correlated with a proper function of organs and hormones, most of male infertility cases because of sperm abnormalities which categorized by whether they affect sperm count, sperm movement, or sperm shape (1). Sperm abnormalities caused by lots of factors, including, disease, lifestyle and chemical exposure, but many causes of sperm abnormalities are still unknown (2). Previous studies $(3,4)$ approved that $\mathrm{CCl}_{4}$ is a chemical exposure cause oxidative stress due inducing free radical production which cause oxidation of germ cells in the testes. Free radicals contribute to male infertility, damaging cells, tissues and organs $(5,6)$. To maintain and protect normal cell function, excess of free radicals must be inactivated continuously by antioxidants in seminal plasma and block the formation of new reactive oxygen species ROS or keep removing generated ROS (3).

Herbal is the oldest form of medicine, it is used widely in practiced form of medicine (7). Alhagi, is a genus from family Fabaceae, Its distributed in many countries of Asia, Europe and Australia. Commonly it has lots of names like Camel thorn or Aqool (8). The previous studies showed that Alhagi maurorum plant contained many secondary metabolites, it exerted antibacterial, anti-inflammatory, antipyretic, analgesic, antioxidant, gastrointestinal, cardiovascular, diuretic, and dermatological, and many other effects (9-11). Very rare studies demonstrated the effect of aqueous extract of alhagi plant in fertility of males therefore the present study was designed to explore the protective effect of Alhagi maurorum on testicular dysfunction-induced by $\mathrm{CCl}_{4}$ in rats.

\section{Materials and methods}

\section{Experiment design}

Twenty-four adult male rat average weight is $200-250 \mathrm{~g}$ housed at the experimental animal unit, College of Veterinary Medicine, University of Tikrit. Feed and water were provided all time. Rats divided randomly into four groups, first was control group which administered with physiological saline $0.9 \%$ and the other three groups administered once with $\mathrm{CCl}_{4} 3 \mathrm{ml} / \mathrm{kg} \mathrm{B}$.W. $(5,6)$, aqueous extract of Alhagi maurorum $300 \mathrm{mg} / \mathrm{kg}$ B.W (12) and aqueous extract together with $\mathrm{CCl}_{4}$ respectively. The animals were dosed orally once daily for 30 days using gavage needle.

\section{Preparation of plant material}

Aerial parts of Alhagi maurorum were collected from Alalam desert, Sallahidin province in the middle of Iraq. After scientific approval by botanical experts, leaves boiled in $3 \mathrm{~L}$ of distilled water for 1 hour then dried by reduced pressure. Powder kept in sterile container until use (7).

\section{Active phytochemical compounds}

Active phytochemical compounds (phenolic acids and flavonoids) determined in aqueous extracts (AE) of leaves using method of high-performance liquid chromatography (HPLC). Plant extract were performed on Shimadzu HPLC system (Fig. 1 and 2). Phenolic compounds separated on a Thermo Scientific Hypersil Gold reverse phase (RP-18) column, $250 \mathrm{~mm} \times 4.6 \mathrm{~mm} \mathrm{C18}$ is the stationary phase. The gradient maintained at flow rate $1-2 \mathrm{ml} / \mathrm{min}$, the time of run was over $10 \mathrm{~min}$. The binary mobile phase consisted of a solvent A (water: acetic acid; 99:1; v/v) and solvent B (acetonitrile). The gradient elution from the column was achieved with $13 \%$ of solvent B until 10 min. The phenolic acids and flavonoids were detected by a UV detector at wavelength $200-500 \mathrm{~nm}$. The chromatographic peaks were identified by comparing retention time of analytics with that of reference compounds (Fig. 1) $(13,14)$.

\section{Blood samples}

At the end of the experiment, blood samples were taken by retro-orbital vein placed in a test tube free of anticoagulant then placed in the incubator at $37{ }^{\circ} \mathrm{C}$ then centrifuged at $3000 \mathrm{rpm}$ for 15 minutes. Serum were kept at $-20{ }^{\circ} \mathrm{C}$ until biochemical tests were carried out.

\section{Histological preparation}

Testes tissue were immediately put in formalin $10 \%$ for 24 hours. Dehydrated by graded alcohol series then embedded in paraffin. Samples cut into $5 \mu \mathrm{m}$ sections, stained using hematoxylin and eosin (H\&E). Slides examined using light microscopy under 40x magnification (15).

\section{Sperm count assay}

Male rats were killed and the cauda epididymis were excised and then placed in petri dish containing 9.8 of formalin buffer $10 \%$. Cauda epididymis was then cut using a fine scissors to make sperm suspension. Eosin stain added to suspension, the sperm counted using hemocytometer (improved Neubauer, Deep 1/10 mm, LABART, Germany). Using following equation, total sperm number $=(\mathrm{N} / 80) \mathrm{x}$ $400 \times 1000 \times 10 \times 10(16)$. 


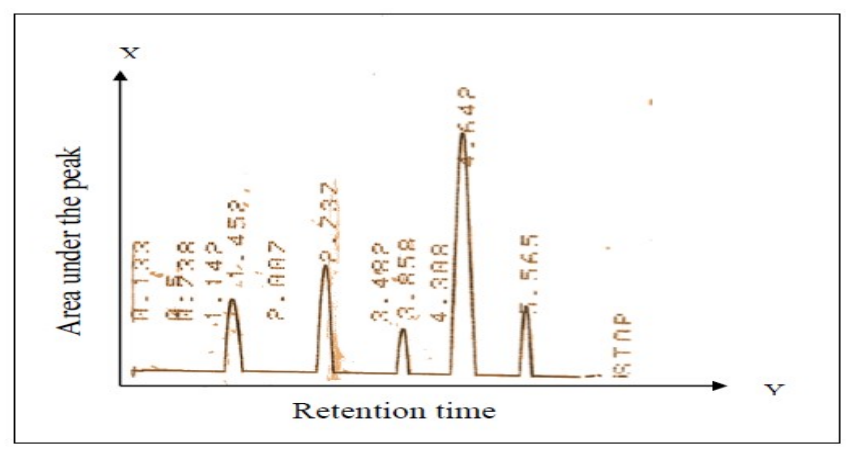

Figure 1: Flavonoids in aqueous extract of Alhagi mauroum separated by HPLC.

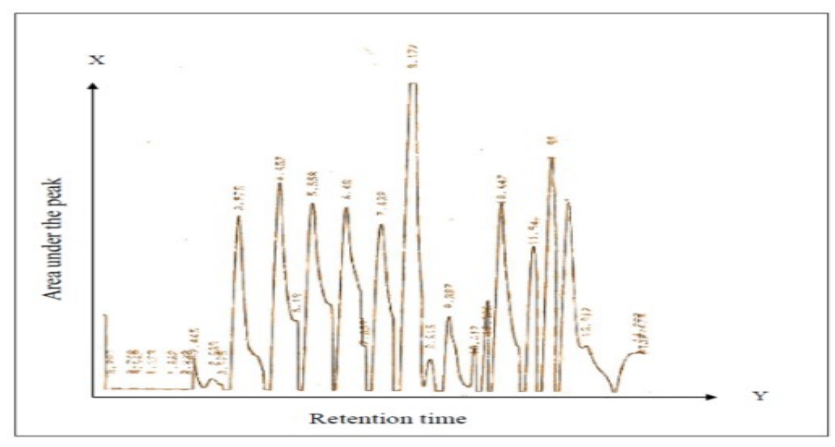

Figure 2: Phenols in aqueous extract of Alhagi mauroum separated by HPLC.

\section{Abnormality and viability assay}

Cauda epididymis was excised and then placed in petri dish containing physiological solution $0.9 \%$. Cauda epididymis was then cut a fine scissors. Smears prepared with stains $(0.2 \mathrm{~g}$ of Eosin and $0.6 \mathrm{~g}$ of Fast green) dissolved in distilled water and ethanol in ratio 2:1. Abnormality detected according to the head, neck and tail of sperm. Live/dead ratio determined using the stains $1 \%$ Eosin and $5 \%$ Nigrosine in 3\% sodium citrate dehydrate solution according to (17).

\section{Glutathione assay}

The test was performed by using the laboratory analysis kit (OxiselectTM Total Glutathione (GSSG / GSH) assay kit) prepared by Cell Biolabs Inc., according to the company's approved mechanism and the tools required for the method of work (18). Figure 3 shows the standard curve of GSSG.

\section{Superoxide dismutase assay}

The SOD Assay kit - WST, manufactured by Dojindo, Japan and using ELISA, was used to estimate the level of the enzyme and according to the manufacturer's method of operation (19).

\section{Malondialdehyde assay}

The NWLSSTM Malondialdehyde Assay was used by Northwest Life Science Specialists, LLC to measure the concentration of MDA in the serum and tissue extract, according to the work mechanism and materials required and prepared by the company (19).

\section{Statistical Analysis}

Data were recorded and analyzed using one-way analysis of variance (one-way ANOVA) test. Group differences were determined using Duncan multiple range test. $\mathrm{P}<0.01$ was considered statistically significant value (20).

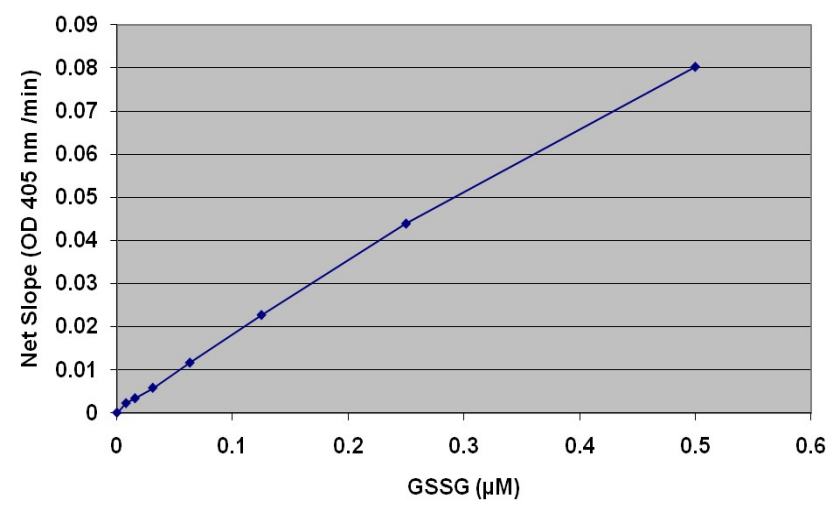

Figure 3: The standard curve for GSSG.

\section{Results}

Active phytochemical compounds (phenolic acids and flavonoids) have been detected in Alhagi marourum leaves extract (Table 1) and (Table 2). The results referred that treatment with $\mathrm{CCl}_{4}$ caused a significant decrease $(\mathrm{P}<0.01)$ in sperm count (Oligospermia), normal sperm, live sperm (Teratospermia), GSH, SOD levels and significant increase in dead and abnormal sperm ratio and MDA level compared to control group (Fig. 4-9). While the treatment with aqueous extract $\mathrm{AE}$ plus $\mathrm{CCl}_{4}$ showed significant increase $(\mathrm{P}<0.01)$ in sperm counting, live and normal sperm and GSH level and a significant decrease in the percentage of dead and abnormal sperm and the level of MDA compared to $\mathrm{CCl}_{4}$ group. The treatment with aqueous extract showed a significant increase $(\mathrm{P}<0.01)$ in $\mathrm{GSH}$ level and no significant difference in the rest of the studied variables compared to the control group in significant value $(\mathrm{P}<0.01)$ (Fig. 4-9). Testes tubules of $\mathrm{CCl}_{4}$ group are almost empty of sperm (Fig. 10-B) in compare to control(Fig 10-A), most of cells show damages in vital cell components. In $\mathrm{CCl}_{4}$ plus aqueous extract group(Fig. 10-C), majority of sperm cells in the stages of morphological transition and look similar to normal but, less dense in compare to the normal state (Fig. 10-D). 
Table 1: Detecting flavonoid in aqueous extract of Alhagi maurorum using HPLC method (table show retention time, peak area and flavonoid concentration)

\begin{tabular}{lccc}
\hline Flavonoid & $\begin{array}{r}\text { Retention } \\
\text { time }\end{array}$ & $\begin{array}{c}\text { Peak } \\
\text { area }\end{array}$ & $\begin{array}{c}\text { Concentration } \\
\mu \mathrm{g} / \mathrm{ml}\end{array}$ \\
\hline Kaempferol & 1.45 & 11742 & - \\
Chrysoeriol & 2.73 & 22094 & 147.41 \\
Isorhamentin & 3.85 & 17381 & 214.9 \\
Chrysoeriol-7-oxylosoid & 4.64 & 30215 & 118.49 \\
$\begin{array}{l}\text { Isorhamnetin-3-0-b-d- } \\
\text { apiol Galactopyranoside }\end{array}$ & 5.56 & 19538 & 263.79 \\
\hline
\end{tabular}

Table 2: Detecting phenols in aqueous extract of Alhagi maurorum using HPLC method (table show retention time, peak area and phenol concentration)

\begin{tabular}{lccc}
\hline Phenols & $\begin{array}{c}\text { Retention } \\
\text { time }\end{array}$ & $\begin{array}{c}\text { Peak } \\
\text { area }\end{array}$ & $\begin{array}{c}\text { Concentration } \\
\mu \mathrm{g} / \mathrm{ml}\end{array}$ \\
\hline Caffeic acid & 1.32 & 16216 & 80.33 \\
Vanillic acid & 2.23 & 9797 & 46.47 \\
Naringin & 2.44 & 14657 & 223.67 \\
Syringic & 2.93 & 22519 & 175.42 \\
Chlorogenic & 3.22 & 5980 & 219.26 \\
Coumaric & 3.57 & 61599 & 186.41 \\
Ferulic acid & 4.65 & 47859 & 167.56 \\
Sinapic acid & 5.19 & 10479 & 201.61 \\
Isoqurectrin & 5.55 & 62223 & 45.42 \\
Rutin & 6.48 & 54058 & 174.56 \\
Iutolin & 7.05 & 9170 & 0.178 \\
\hline
\end{tabular}

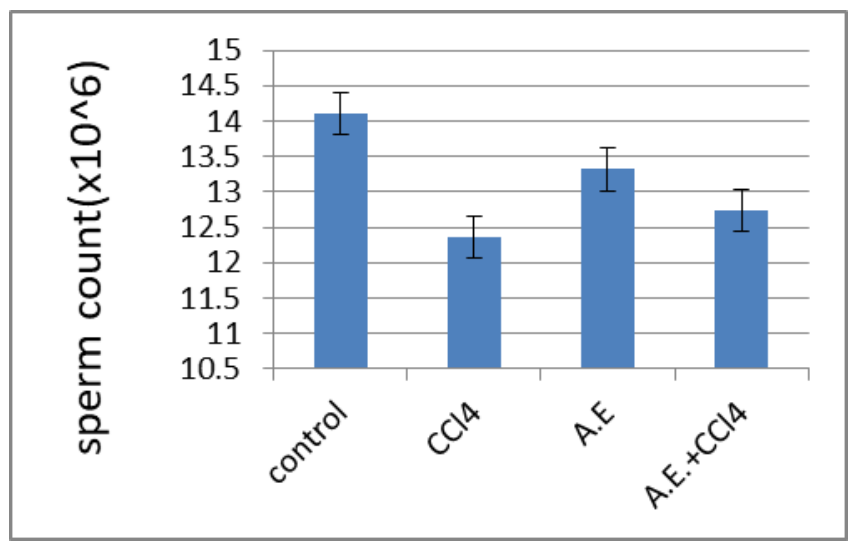

Figure 4: Effect of aqueous extract of Alhagi maurorum on sperm count in rats exposed to $\mathrm{CCl}_{4}$. Value were expressed as means \pm SE from 6 rats per group. Significant value $\mathrm{P} \leq 0.01$.

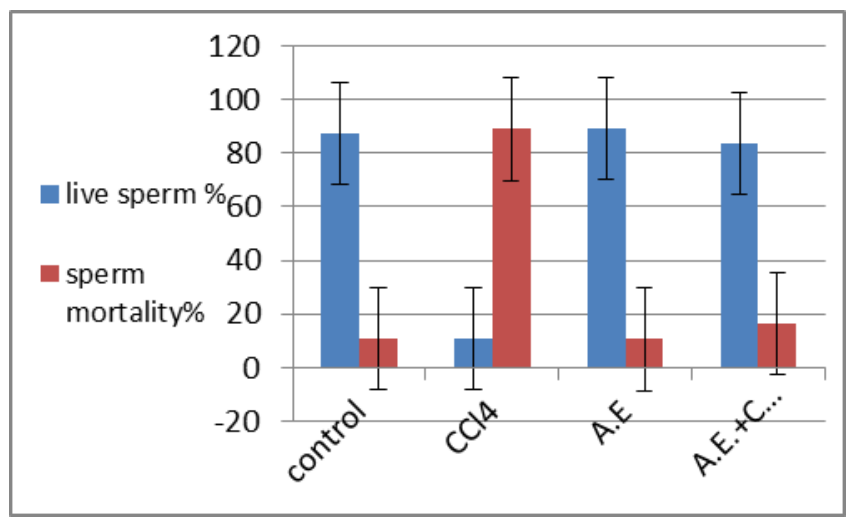

Figure 5: Effect of aqueous extract of Alhagi maurorum on ratio of live/dead sperm in rats exposed to $\mathrm{CCl}_{4}$. Value were expressed as means \pm SE from 6 rats per group. Significant value $\mathrm{P} \leq 0.01$.

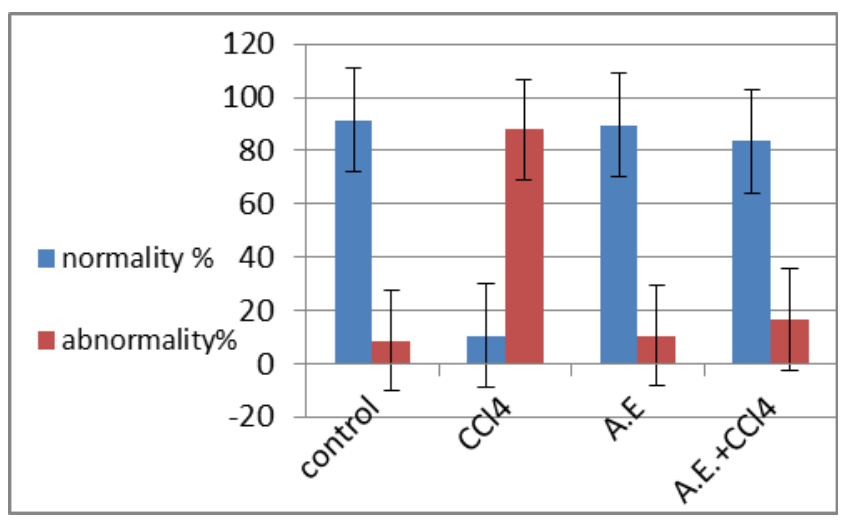

Figure 6: Effect of aqueous extract of Alhagi maurorum on sperm morphology in rats exposed to $\mathrm{CCl}_{4}$. Value were expressed as means $\pm \mathrm{SE}$ from 6 rats per group. Significant value $\mathrm{P} \leq 0.01$.

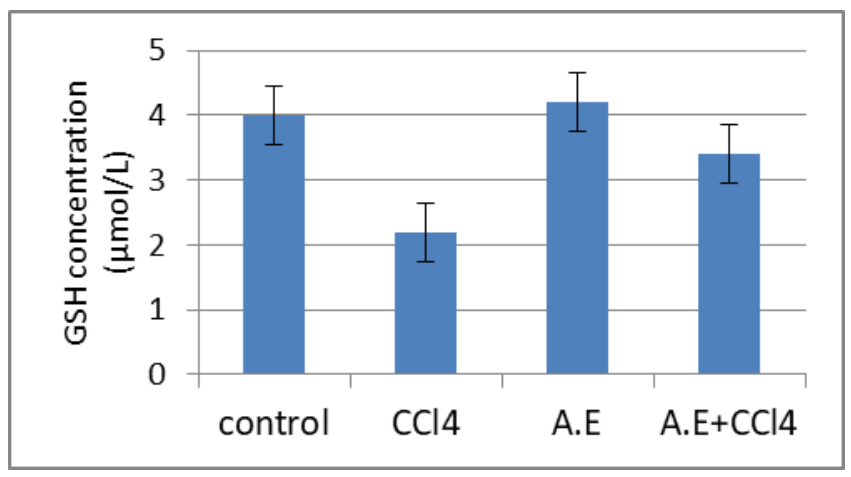

Figure 7: Effect of aqueous extract of Alhagi maurorum on GSH level in serum $\mathrm{n}$ in rats exposed to $\mathrm{CCl}_{4}$. Value were expressed as means $\pm \mathrm{SE}$ from 6 rats per group. Significant value $\mathrm{P} \leq 0.01$. 


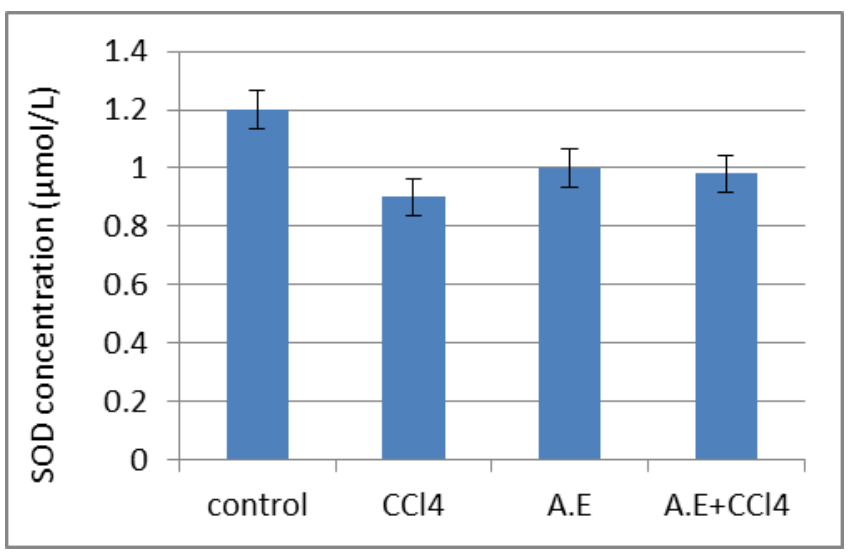

Figure 8: Effect of aqueous extract of Alhagi maurorum on Super oxide dismutase level in serum $\mathrm{n}$ in rats exposed to $\mathrm{CCl}_{4}$. Value were expressed as means $\pm \mathrm{SE}$ from 6 rats per group. Significant value $\mathrm{P} \leq 0.01$.
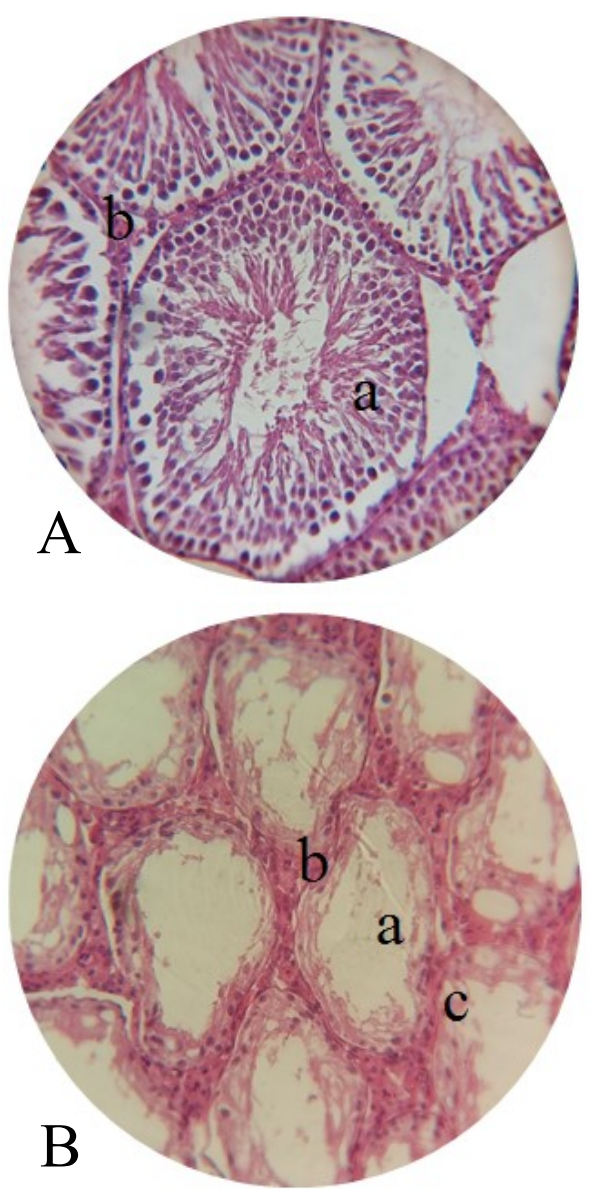

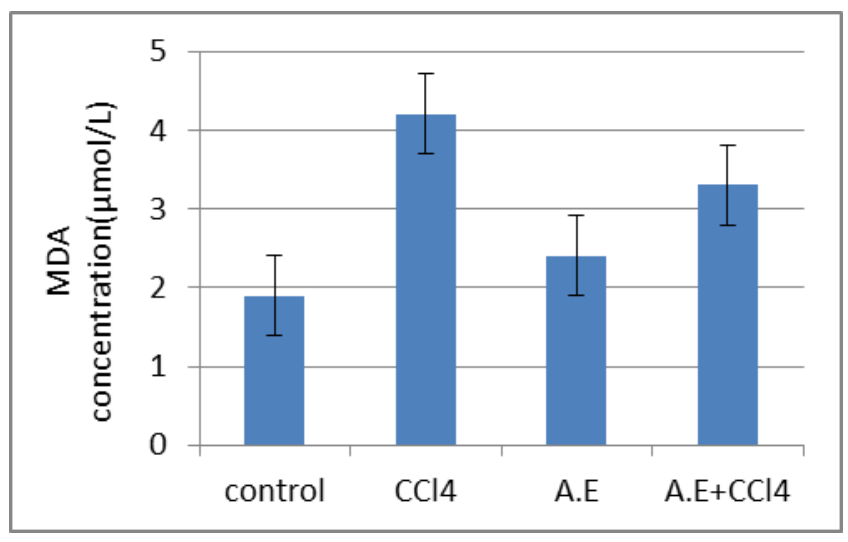

Figure 9: Effect of aqueous extract of Alhagi maurorum on MDA level in serum $\mathrm{n}$ in rats exposed to $\mathrm{CCl}_{4}$. Value were expressed as means \pm SE from 6 rats per group. Significant value $\mathrm{P} \leq 0.01$.

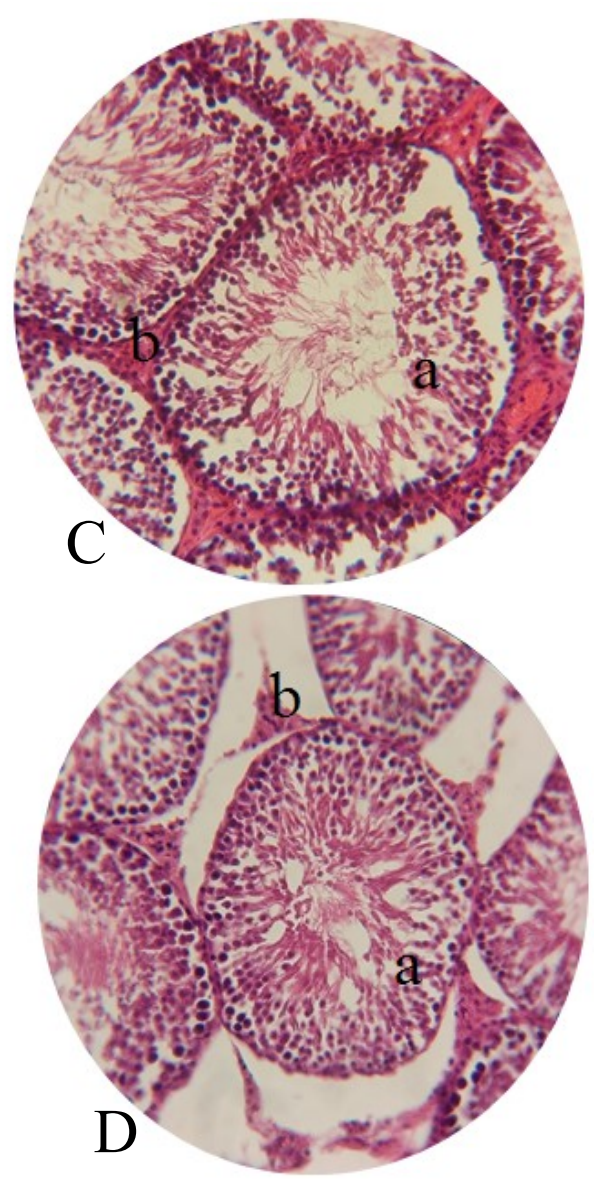

Figure 10: (A) control group, (a) normal spermatogenesis, (b) normal Leydig cell. (B) CCl4 group, (a) Necrosis, (b) spermatogonia, (c) Leydig cells. (C) Aquoies extract of Alhagi maurorum group, (a) normal spermatogenesis, (b) normal Leydig cell. (D) CCl4 + aquoies extract of Alhagi maurorum group, (a) normal spermatogenesis, (b) Leydig cell. H\& E stain, 40x. 


\section{Discussion}

Male germ cell through stages of differentiation generate reactive oxygen species ROS in low levels to regulate sperm differentiation. ROS level maintained by antioxidant (21). Sperm plasma membrane contain unsaturated fatty acid and these attacked by ROS leads to chemical reaction that called lipid peroxidation (22), and that reduces membrane enzymes activity, ion channels and the membrane fluidity, resulting inhibition in required mechanisms for production and fertilization of sperm (23) (Fig. 10-B). Excess ROS overwhelm antioxidant defense called oxidative stress $(22,23)$. Treatment using $\mathrm{CCl}_{4}$ cause oxidative stress of male reproductive system (Fig. 5, 6 and 7) which linked negatively with sperm production, Normality and sperm vitality. (Fig. 4, 5 and 6) in compare to control(Fig. 10-A) and that combined with $(3,4)$. ROS promote apoptosis leading to decreased sperm concentration and increased level of caspases and proteases which increase apoptosis in mature spermatozoa (24). Researchers mentioned that the sperm is more susceptible to oxidative stress than other cells because of the limited amount of cytoplasm and the concentration of ROS suppressing antioxidants in the mature sperm in addition to high levels of unsaturated fatty acids in the sperm structure (11). The health and fertility of sperm dependent on the antioxidants to protect plasma membrane surrounding acrosome and tail (25). The leaves extract of Alhagi maurorum contain polyphenols(Table 2) (Fig. 3) and flavonoids (Table 1) that has antioxidant potential activity $(26,27)$, most flavonoids and phenols are metabolized in vivo, which can effectuate antioxidant capacity. The main phytochemical classes that comprised are phenolic acids and flavonoids. Flavonoids include several subclasses (24) (Table 1). Flavonoid-rich foods, correlated with a lower risk of many diseases (28). the aqueous extract increased glutathione GSH, SOD levels and decreased MDA level in serum in subject's exposure to oxidative stress (Fig. 7, 8 and 9). MDA is produced due to the degradation of the peroxides of unsaturated fatty acids. It is considered biomarker to determine the rate of oxidative damage (24). Testicular tissue is susceptible to oxidative stress (29), so testes protect itself from damage using antioxidants and free radical scavengers to maintain that steroidogenic and spermatogenic functions are not impacted by oxidative stress in healthy rats (25) (Fig. 8, 9 and (Fig. 10-A). Histological changes had been noticed in subject's exposure to oxidative stress induced by $\mathrm{CCl}_{4}$ (Fig. 7, 8, 9 and 10-B) while maintain antioxidant and free radical scavengers in subject's exposure to oxidative stress give a positive result (Fig. 7, 8, 9 and 10-D). antioxidants have the ability to avoid damage by counteracting free radicals or preventing their formation in the testicular cells and prevent oxidation chain by finding primer free radicals, preventing various diseases $(30,31)$. It could be concluded that the aqueous extract of Alhagi maurorum have a positive effect on male reproduction and antioxidants in rats exposed to oxidative stress. (Fig. 10-C).

\section{References}

1. Zegers-Hochschild F, Adamson, GD, deMouzon J, Ishihara O, Mansour R, Nygren, K. International committee for monitoring assisted reproductive technology (ICMART) and the World Health Organization (WHO) revised glossary of ART terminology. Fert Stert. 2009;92(5):1520-4.

2. Davies MJ, Moore VM, Willson KJ, Van Essen P, Priest K, Scott H. Reproductive technologies and the risk of birth defects. N Engl J Med. 2012;366(19):1803-13.

3. Agarwal A, Virk G, Ong C, Plessis S. Effect of oxidative stress on male reproduction. World J Mens Health. 2014;32(1):1-17.

4. Gharagozloo P, Aitken RJ. The role of sperm oxidative stress in male infertility and the significance of oral antioxidant therapy. Hum Reprod. 2012;26:1628-40.

5. Aitken R, Roman S. Antioxidant systems and oxidative stress in the testes. Oxid Med Cell Longevity. 2008;1(1):15-24.

6. Misro MM, Choudhury L, Upreti K, Gautam D, Chaki SP, Mahajan A $\mathrm{S}$, Babbar R. Use of hydrogen peroxide to assess the sperm susceptibility to oxidative stress in subjects presenting a normal semen profile. Inter J Androl. 2004;27:82-87.

7. Neamah NF. A pharmacological evaluation of aqueous extract of Alhagi maurorum. Glob J Pharmacol. 2012;6(1):41-6.

8. Loizzo M, Rashed K, Said A, Bonesi M, Menichini F, Tundis R. Antiproliferative and antioxidant properties of Alhagi maurorum Boiss (Leguminosae) aerial parts. Indus Crop Prod. 2014;53:289-295.

9. Muhammad G, Hussain MA, Anwar F, Ashraf M, Gilani AH. Alhagi: a plant genus rich in bioactives for pharmaceuticals. Phytother Res. 2015;29(1):1-13

10. Al-Snafi A. Alhagi maurorum as a potential medicinal herb: an overview. Inter J Pharm Rev Res. 2015;5:130-136.

11. Sheweita SA, Mashaly S, Newairy AA. Changes in oxidative stress and antioxidant enzyme activities in streptozotocin-induced diabetes mellitus in rats: Role of Alhagi maurorum Extracts. Oxid Med Cell Longevity. 2016;1:1-8.

12. Rehman JU, Aktar N, Khan MY, Ahmad K, Ahmad M, Sultana S. Phytochemical screening and hepatoprotective effect of Alhagi maurorum boiss (Leguminosae) against paracetamol-induced hepatotoxicity in rabbits. Trop J Pharm Res. 2015;14:1029-34.

13. Mauricio J, Penarrietaabc J, Alvaradoa A, Akessonb B, Bergenstahlc B. Separation of phenolic and flavonoid compounds from foods by reversed-phase high performance liquid chromatograph. Bolivian $\mathrm{J}$ Chem. 2007;24(1):1-4.

14. Khanam Z, Sam K, Mohd N, Ching C, Haq Bhat I. Analyses and DNA cleavage activity of Malaysian Averrhoa carambola L. fruit extracts. J Kin Saud Uni Sci. 2015;27:331-337.

15. Bankroft JD, Stevens A. Theory and practice histological technique. $5^{\text {th }}$ ed. London: Churchill Livingston; 1982. P.25-28.

16. Pant N, Murthy RC, Srivastava SP. Male reproductive toxicity of sodium arsenate in mice. Hum Exp Toxicol. 2004;23:399-403.

17. Wells ME, Awa OA. New technique for assessing acrosomal characteristic of spermatozoa. J. Diary Sci. 1970;53:227.

18. Hall JA. Effect of transport on blood selenium and glutathione status in feeder lambs. J Anim Sci. 2014;92:4115-4122.

19. Halliwell B, Chirico S. Lipid peroxidation: its mechanism, measurement and significance. Am J Clin Nutr. 1993;57:715-24.

20. Al-Mohammed NT, Al-Rawi KM, Younis MA, Al-Morani WK. Principles of statistics. Mosul: Mosul University Press; 1986. P.85-94.

21. Halliwell B. Oxidative stress and neurodegeneration: where are we now? J Neurochem. 2006;58:1634-36. 
22. Wang X, Sharma RK, Sikka SC, Thomas AJ, Falcone T, Agarwal A. Oxidative stress is associated with increased apoptosis leading to spermatozoa DNA damage in patients with male factor infertility. Fert Stert. 2003;80:531-535.

23. Sikka S. Role of oxidative stress and antioxidants in andrology and assisted reproductive technology. J Androl. 2004;25, 5-18

24. Lotito SB, Frei B. Consumption of flavonoid-rich foods and increased plasma antioxidant capacity in humans cause consequence or epiphenomenon. Free Radic Biol Med. 2006;41(12):1727-46.

25. Asadi N, Bahmani M, Kheradmand A, Rafieian-Kopaei M. The impact of oxidative stress on testicular function and the role of antioxidants in improving it: A review. J Clin Dig Res. 2017;11(5):15.

26. Laghari AH, Memon A, Memon S, Nelofar A, Khan KM, Yasmin A. Determination of free phenolic acids and antioxidant capacity of methanolic extracts obtained from leaves and flowers of camel thorn (Alhagi maurorum). Nat Prod Res. 2012;26(2):173-6.
27. Ahmad N, Bibi Y, Saboon I, Zahara K, Idrees S, Nadia K, Bashir T, Tabassum S, Mudrikah I. Traditional uses and pharmacological properties of Alhagi maurorum: A review. Asian Pacific J Trop Dis. 2015;5(11):856-861.

28. Peterson J, Lagiou P, Samoli E, Lagiou A, Katsouyanni K, La Vecchia C, Dwyer J, Trichopoulos D. Flavonoid intake and breast cancer risk: a case-control study in Greece. Br J Cancer. 2003;89:1255-1259.

29. Romeo C, Antonuccio P, Esposito M, Marini H, Impellizzeri P, Turiaco N. Hydrophilic vitamin e like antioxidant reduces testicular ischemia perfusion injury. Urol Res. 2004;32:367-71.

30. Szabo C, Ischiropoulus H, Radi R. Peroxynitrite biochemistry, pathophysiology and development of therapeutics. Nat Rev. 2007;6:662-79.

31. Bahmani M, Mirhoseini M, Shirzad H, Sedighi M, Shahinfard N, Rafieian M. A review on promising natural agents effective on hyperlipidemia. J Evid Based Compl Altern Med. 2015;20(3):228-38. 